\title{
Effect of Single Window System Procedures on Cargo Clearance Efficiency in Kenya: A Case for Mombasa Port
}

\author{
Billy N. Kabui ${ }^{1 *}$ Thomas Gakobo ${ }^{2}$ Dr. Peter Mwaura ${ }^{3}$ \\ 1. Department of Commerce, Laikipia University, P. O. Box 1100 - 20300 Nyahururu Kenya \\ 2. Department of Commerce, Laikipia University, P. O. Box 1100 - 20300 Nyahururu Kenya \\ 3. School of Business, Laikipia University, P. O. Box 1100 - 20300 Nyahururu, Kenya
}

\begin{abstract}
A Single Window Concept is a one-stop facility that allows exchange of information between all parties involved in trade across borders. It is aimed at reducing the complexity, time and costs of clearing goods at the ports. The Concept has been successfully implemented in Kenya in areas such as the Mombasa port, Jomo Kenyatta International airport, Moi International airport and Kenyan borders. The study sought to identify the Effect of Single Window System on cargo clearance efficiency at the port of Mombasa. In particular, to determine its effect on shipping procedures, Pre-clearance permits and Customs goods declaration procedures at the port of Mombasa. The study adopted a quantitative approach targeting a population of 155 respondents. Stratified sampling technique was used to get a sample size of 112 respondents. Data was collected using a structured questionnaire with Likert scale measurement. Data was collected and analyzed using descriptive as well as inferential statistics. The study found that Single Window concept has positive effect on Shipping procedures ( $p$-value 0.952), Pre-clearance permits ( $p$-value 0.861), Customs goods declaration procedures ( $p$ value 0.950 ) and hence improved cargo clearance efficiency at the port of Mombasa. The study recommends more studies to be done on variables that affect cargo clearance efficiency at the port of Mombasa which were not covered under this study.
\end{abstract}

Keywords: Concept, One-stop facility, Cargo clearance, Pre-clearance permits, Customs goods declarations, Regulatory agencies, Electronic cargo authentication.

DOI: $10.7176 / \mathrm{EJBM} / 11-24-11$

Publication date: August $31^{\text {st }} 2019$

\section{Introduction}

The Single Window Concept (SWC) in a theoretical perspective, is a facility that allows on-line lodgment of trade related information through a single electronic portal. The information is then disseminated to the various regulatory agencies and private institutions for processing. In international trade, the merchants involved access all import or export related regulatory services through the system. The system is either a physical structure i.e. building or electronic, which basically provides a single point of entry and processing of data related to cross border trade. The system usually managed by a Single Agency through the various models such Hybrid, Stand alone or integrated system. (Abeywickrama \& Wickramarachchi, 2015).

The system replaces paper-based transactions and reduces physical movement and interaction between merchants and government officers, hence reducing inefficiencies in the process. The system has in-built business rules for each individual process, to enable compliance with regulatory agencies and other parties involved in cross border trade. (ESCWA, 2011). A Single agency is entrusted with the management of the system and basically oversees the implementation of the changes from paper based business processes to electronics-based processes. This is one of the most challenging aspect of implementation of the systems and poses serious issues to do with change management. (ESCWA, 2011).

ESCWA (2011), defines SWC as an open system integrated with the trading community such as banks who enable the trading community to make online payments for their transactions using the Payment gateway in the Single Window system. Electronic receipts can be integrated directly from the banks into the system accounting module. It also provides a platform where Shipping Lines, Airline companies and their appointed agents have to provide the manifest data on an electronic format, which is distributed to the various government agencies by the system. It also provides a messaging function, which updates/alerts the government agencies at various release points to release the cargo. This improves clearance time and overall the cost of doing business in the country. The system also has a Risk Management module which the various government agencies can use to manage the various risks aspect which are represented in the cross border trade. Setting up of the Single window is a very expensive affair as has been a case for Kenya and many other countries which have implemented the concept. Implementation of the Single Window Concept is a very expensive affair and requires investment in both financial and human resources to enable successful implementation of the concept. 
project (Kabuga 2013). The system was initially targeting port handling, Customs and Partner government agencies procedures within the port of Mombasa. The project was funded by the World Bank with Kenya Port Authority and Kenya overseeing the overall implementation of the project. The government saw the potential interms of impact in cross border trade, and decided to expand it to cover the airports and all other borders within the country, hence managing all transport modes which include air, rail, road and sea.

The project started in 2007 with development of a project charter, which clearly defined the objectives and strategies for the implementation of the SWC in Kenya. One of the strategy was to re-engineer some procedures that were contributing to inefficiencies in cargo clearance. The next strategy was to how manage various stakeholders involved in cross border trade. The stakeholders included government regulatory agencies and the players from the private sector such the Customs brokers, and cargo handlers with the port and airport. The stakeholders were engaged through structured forums such workshops and change agent networks. This was to ensure all stakeholders involved in cross border were engaged right from the start of the project with an aim of promoting ownership and reduce incidences of resistance to change.

In 2011, the government formed Kenya Trade Network Agency (KENTRADE) to manage implementation of the SWC in the country. The agency main objective was to facilitate international trade through implementation and operationalization the SWC in Kenya. This geared towards reducing delays and lowering cost of doing business in the country by reducing cargo dwell time from 14 days to three days at the port, I week to one day at the airport and 2 days to a maximum of one hour at the border. The government had identified processes that were inefficient and were contributing towards delays in cargo clearance thus contributing to congestion at the port and airports in the country. One of the in efficiencies identified was mostly the manual and some cases semi-automated cargo clearance procedure. These inefficient procedures contributed to delays in cargo clearance, increased cost of doing business, corruption and reduced the country's competitiveness compared to its peers in the region (Kabuga, 2013).

The end product of the stakeholder's engagements was production of business process reengineering report which was used to development the system requirement specifications which were used to develop the system. The system was launched on $31^{\text {st }}$ October 2013 and was implemented in phases; In Phases 1 which include Pre and Post Clearance Documentation Modules and Phase 2 which Clearance Permits Module for both exports and imports. The project has achieved a lot of milestones, which has seen completion of Implementation of 20 Modules which integrates 30 government agencies involved in cross border trade.

\section{Statement of the Problem}

Cargo clearance procedures are one of the major bottlenecks in product supply chains in Kenya. The delays at border crossings and ports caused by lengthy, complex procedures and excessive paperwork have created a negative impact on trade and increased cost of doing business in the country. Other challenges include conflicting legal mandates from various government agencies and use of semi-automated procedures. These challenges have led to in-efficient processes which have caused delays in cargo clearance thus affecting port operations and overall cost of doing business in the country. The challenges experienced have also affected trade across borders in Kenya with key stakeholders raising concerns due to frequent disruption of their business, as a result of delays in cargo clearance at various ports. The delays have increased the cost of clearing cargo and at the long increased the prices of imported goods into the country. It is in this background, that the government implemented the Single Window system with an aim of addressing the efficiencies in cargo clearance process. The study therefore seeks investigate the effect of Single Window System on cargo clearance efficiency in Kenya, paying attention to the port of Mombasa.

\section{Review of Related Literature}

This section covers three theories which highlight the relationship between cargo clearance efficiency and Single Window system implementation at the port of Mombasa. The study will be guided by three theories; System theory, Change management theory \& Theories on Technology Acceptance.

\subsection{System Theory}

It's important for an organization to continually scan its environment to enable it respond to any change (Cao and McHugh, 2005). The purpose of environmental scan is to understand the market dynamics such as competition, technological advancements and others (Byeon, 2005). The application of system theory is very important in an organisation that is applying technology to change the way it operates. The theory mainly concentrates on control mechanism applied for the change and feedback received within the organization. It aims at control of negative feedback by creating an equilibrium and brings the needed stability when implementing the change (Byeon, 2005). The theory enables the business to remain in-tandem with changing environment.

The theory defines an organization as set of a relationship comprising of various actors/stakeholders each having their own role and which have an influence with it performance. These actors while playing their individual role 
are under set of defined rules, which determine how they interact with the organization (Mason, 2007).

System theory tends to bring understanding to the business environment complexities, by enabling the management in responding more effectively to the business disruptors. This is achieved through bringing understanding of the business processes and how they aid in managing the uncertainties and their implications. The theory also addresses the aspect of open and closed systems. The theory tries distinguish between the two by bringing an understanding on how they are. In open system, the theory informs that and change in the business environment will affect the internal systems within an organization. If the organization does not respond effectives to the changes, then it will affect its overall performance (Shafritz et al, 2005; Wang, 2004). Closed system on the other hand, are not significantly affected by changes with external environment and are more resilient to when the changes occur.

\subsection{Theory on Technology Acceptance}

This theory resonated from the theory of reasoned action (TRA). The theory examines the level of information system acceptability through prediction of the prevailing audience Davis (1989). It predicts how the various users of the information system accept the various communication medium and how they help in modification of the same. The theory implies that, the level of acceptability, of an information system is determined by various factors, which include; the benefits and ease of the system. Perceived usefulness is defined as being the degree to which a person believes that the use of a system will improve his performance. In this study, women entrepreneurs would adopt mobile technology when they perceive that it is useful in their business operations.

\subsection{Business Process Re-engineering theory}

Tylor (1880) explained that the purpose of business reengineering is to make them the best and efficient over others, in order to improve business performance. He noted that managers could discover the best processes for performing work and reengineer them to optimize productivity. BPR echoes the classical belief that there is one best way to conduct tasks. In Taylor's time, technology did not allow large companies to design processes in a cross- functional or cross-departmental manner. Specialization was the state-of-the-art method to improve efficiency given the technology of the time. To reap lasting benefits, companies must be willing to examine how strategy and reengineering complement each other by learning to quantify strategy (in terms of cost, milestones, timetables); by accepting ownership of the strategy throughout the organization; by assessing the organizations current capabilities and processes realistically; and by linking strategy to the budgeting process. Otherwise BPR is only a short term efficiency exercise (Garvin, 1998).

\section{Empirical review}

\subsection{The Single Window System}

A study conducted by World Customs Organization (WCO) survey 2011, found that the Single Window system has been a huge advantage for the trading community. It has speeded up the processing of trade information, has enabled risk management especially for concerned Government agencies, has enhanced compliance in the private sector and provides better service to businesses due to efficiencies.

Tosevska and Trpcevska, (2011), established that after implementation of Single Window system in Macedonia, stakeholders both from government and private sector were able to reap benefits which simple search mechanisms; straightforward procedures for obtaining a licenses; resource savings (time, costs and human resources); improved communication; and contact with and resolution of problems by CARM the responsible agency for its functioning (Kostovski 2011). Increased compliance level was also identified with an increase in number of licenses issued in 2010 in comparison to 2009 showed an increase with 52,081 license issued in 2010, compared with 28,632 in 2009. The results of the research indicated that the Single Window System had helped to facilitate trade by speeding up the process of obtaining licenses, providing savings in terms of time, human resources and costs, and generally, in facilitating the activities of economic operators.

\subsection{Shipping Procedures}

Shipping procedure according to UIA (2000) are often slow, cumbersome, and expensive. This has led to increasing the cost of doing business and also access to world markets. By impeding the smooth flow of trade and efficient operation of the means of transport UIA (2000) noted that unwieldy procedures and excessive paperwork contribute to the congestion of ports, warehouses and stacking areas. It is not unusual for customs or other formalities to require the unnecessary unloading and reloading of goods, thus increasing the risks of pilferage or damage attendant upon the goods being held without proper storage. The role of forwarding agencies that have representatives in the main overseas markets is underdeveloped, even though they could facilitate the speedy movement of goods; at the same time the capabilities of strictly local firms are limited. The effective result is a hidden inflationary tax which is eventually borne by the final consumer of the goods (UIA, 2000).

Costly and complicated procedures are also a serious obstacle to the expansion of trade, sometimes 
discouraging those capable of export from engaging in external trade at all. In the case of land-locked countries in particular, delays and added costs caused by unsuitable procedures contribute to their products lack of competitiveness in world markets. An integrative approach that takes into consideration all the administrative and commercial aspects of the matter within the framework of a facilitation programme aimed at minimizing formalities, simplifying and streamlining procedures, and harmonizing and standardizing documents, is absent (UIA, 2000).

\subsection{Customs goods declaration procedures}

Customs procedures are only one aspect of improving the overall efficiency of the cargo clearance process. A WCO study of cargo clearance times at Indonesian ports found that the customs clearance process for certain shipment took an average of 6.4 minutes, compared to 159 hours and 23 minutes for other activities involved in cargo clearance (including problems with incomplete documents; red tape involved in releasing goods from warehouses; payment hold-ups and deliberate delays in delivery, even after the release of goods by customs official (APEC 2000).

Another study by the Japan Customs and Tariff Bureau shows that the biggest reduction in total elapsed time from cargo arrival to release between 1991 and 1998 was in the plane-to-warehouse and time-in-warehouse stages of the process (Mikuriya, 2001).

In either case, procedural delays produce time sensitive costs. Such costs can be multiplied if there is an error in documents. Procedural delays in border controls impede road haulage and cause stagnation of goods in the warehouse, which, in turn, raise the transportation fees and the inventory charges.

The introduction of a modern data processing system into the customs clearance process will therefore bring about faster clearance of cargo, improve revenue control and will provide up-to-date accurate information on trade in goods (UNCTAD 2003). A number of countries have reduced clearance time dramatically with automation of processing system. For example as stated above, the Japanese customs reduced the customs clearance time significantly from 50.3 hours to 30.8 hours for air cargo and from 142.1 hours to 81.1 hours for sea cargo; (and the time elapsing between the import declaration to the permission was reduced from 2.3 hours to 0.7 hours for air cargo and from 26.1 hours to 5.6 hours for sea cargo between 1991 to 1998: that means the time required to file the import declaration after the arrival of the cargo was reduced (Mikuriya, 2001).

Philippine customs reduced the time for cargo release from the customs custody from 6-8 days to 4-6 hours for "green channel" shipments and 48 hours for other shipments by introducing an EDI system based on UNCTAD's ASYCUDA++ (Maniego, 1999). Chinese Taipei used to spend 10 to 15 hours for customs clearance of air cargo. Thanks to the use of EDI and pre-arrival screening, actual clearance after the arrival of airplanes takes merely two to four hours.

In yet another study Muyenjwa D.D. (2004) shows that the use of technology gives the customs better targets and productivity. Accordingly, express carriers electronically transmit details of manifest to the New Zealand customs which saves time and paperwork by replacing the old manual manifest system.

There is no doubt, therefore, that the use of Information Communication Technology can improve the control and risk assessment of a customs administration and at the same time allow for a reduction in release time (KRA 2004).

\subsection{Cargo clearance efficiency}

A study conducted by KenTex Cargo (2014) noted that, clearing a consignment at the port of Mombasa can be a daunting experience, confusing, costly and sometimes, seemingly impossible to most. All goods imported or exported into and outside Kenya undergo various tasks through Kenyan customs and Kenya Port Authority (KRA). The procedures include manifest submission and approval, goods declaration, pre-shipment declarations, clearance process which entails sometime verification of goods through scanning or physical verification. These procedures are often marred with issues such as delays, corruption and also loss of goods.

Cargo clearance at the port was identified as a trade facilitation constraint leading to increased cost of doing business in the country (Mombasa port charter, 2014). The constraints identified include; The lack of alignment among Port Community members in discharging their mandates in trade facilitation; Insufficient capacity and ineffective operational models at both the Port terminal and hinterland transport channels; Poor Ship to Shore Interface, Low yard productivity and limitations in Cargo off take capacity; Time-consuming Customs Service Department clearance procedures and interventions by other statutory bodies; Insecurity and time-consuming non-tariff barriers along the Corridor; Corruption and unethical practices by different parties in the logistics supply chain.

\section{Methodology}

This study adopted a descriptive research design, which involved the use of both quantitative and qualitative methods (Mugenda 2003). A descriptive research design was the best for this study as it describes characteristics 
associated with the subject population, and in particular factors that make them behave the way they do. According to Coopers and Schindler (2003), descriptive design discovers and measures the cause and effect of relationships between variables. The descriptive design was selected in this study because it will allow the researcher to gather numerical and descriptive data to assess the relationship between the variables. This made it possible for the researcher to produce statistical information on the effect of Implementation of Single Window system in Kenya specifically targeting the Mombasa port.

The target population comprised of 159 KIFWA members based in Nairobi representing the Clearing \& Forwarding Agents, Association of Kenya Importers \& Exporters, and Kenya Shipping Agents Association (KSAA). Partner government agencies namely Kenya Revenue Authority, Kenya Bureau of Standards, Pharmacy and Poisons board and National Treasury whose cargo clearance processes are being managed using the Single Window system.

According to Mugenda and Mugenda (2003), when the study population is less than 200, a sample size of between $10 \%$ and $30 \%$ is a good representation of the target population. The study uses a sample size of 112 which represents $72 \%$ of total population.

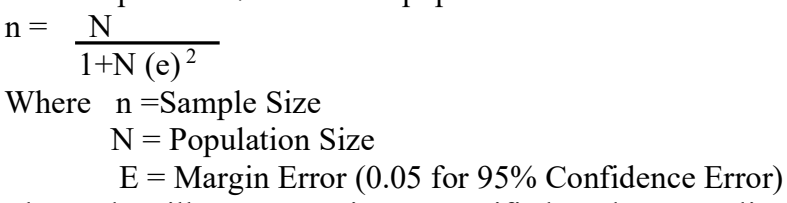

The study will use proportionate stratified random sampling to determine the proportion number in each group. $\mathrm{n}_{\mathrm{h}}=\left(\mathrm{N}_{\mathrm{h}} / \mathrm{N}\right) * \mathrm{n}$

Where $n_{h}=$ Sample size for Stratum

$\mathrm{N}_{\mathrm{h}}=$ Population size for stratum

$\mathrm{N}=$ Population Size

$\mathrm{n}=$ Sample Size

Table 1 - Sample size

\begin{tabular}{|l|c|c|}
\hline Category & Number of employees & Sample size \\
\hline Association of Kenya Importers \& Exporters & 50 & 36 \\
\hline KIFWA secretariat members & 50 & 36 \\
\hline KEBS PVOC department & 15 & 11 \\
\hline Pharmacy and Poisons Board & 5 & 4 \\
\hline KRA Customs Projects office & 30 & 22 \\
\hline National Treasury (Economic Affairs Office) & 5 & 4 \\
\hline \multicolumn{1}{|c|}{ Total } & $\mathbf{1 5 5}$ & $\mathbf{1 1 2}$ \\
\hline
\end{tabular}

Source: Field data (2019)

5.1 Research Instruments

The study administered an online questionnaire as the only data collection instrument due to its advantages in comparison with other data collection methods. The questionnaire was structured in 6 sections; sections A will be respondents identifying variables, section $\mathrm{B}$ was identifying the individual and company profile, section $\mathrm{C}, \mathrm{D}, \mathrm{E}$ and $\mathrm{F}$, will have five sub sections asking questions employing. The questionnaire will use the Likert scale to rank cases from a range of $1-5$ i.e. $1=$ strongly disagree, $2=$ disagree, $3=$ neutral, $4=$ agree, $5=$ strongly agree. Data collected was then analysed using both descriptive by use of mean and standard deviation and inferential statistic using regression analysis, analysis of variance ANOVA and multiple regression analysis.

The regression model used was as follows:

$Y=\beta_{0}+\beta_{1} X_{1}+\beta_{2} X_{2}+\beta_{3} X_{3}+$ ẹ..........

Where:

$\mathrm{Y}=$ Cargo clearance efficiency

$\beta_{0}=$ Constant Term

$\beta_{1}=$ Beta coefficients

$\mathrm{X}_{1}=$ Shipping and Manifest procedures

$\mathrm{X}_{2}=$ Pre-clearance permits procedures

$\mathrm{X}_{3}=$ Customs good declaration procedures

$\mathrm{e}=$ error term (residual term that includes the net effect of other factors not in the model and measurement errors in the dependent and independent variables). 
6. Findings and Discussion

6.1 Demographic

The respondents were asked to state the nature of their business and duration of their business operations.

Table 2 - Nature of business

\begin{tabular}{|l|c|c|}
\hline Nature of business & $\begin{array}{c}\text { No. of respondents } \\
\mathbf{n = 9 6}\end{array}$ & \% of total respondents \\
\hline EXIM (Exporter/Importer) Association. & 25 & 26.04 \\
\hline Freight Forwarders/Clearing Agents & 22 & 22.91 \\
\hline Shipping agent or Consolidator & 15 & 15.63 \\
\hline Terminal Operator/CFS & 10 & 10.42 \\
\hline Government agency/regulators & 24 & 25 \\
\hline
\end{tabular}

Source: Field data (2019)

The study found that $22.91 \%$ of the respondents were Freights forwarders/Clearing Agents, 26.04\% were EXIM (Exporter/Importers), 25\% were government agency/regulators, 15\% were Shipping agents or Consolidators and $10 \%$ were Terminal Operator/CFS. The composition of respondents in terms of their activities confirms that these were respondents with the correct information on the activities in the Cargo clearance business.

6.2 Duration of business operations

The respondents were asked to state the how long they have been in operations. The results are shown in table below;

Table 3 - Duration of business operation

\begin{tabular}{|l|c|c|}
\hline \multicolumn{1}{|c|}{ Duration of business operation } & $\begin{array}{c}\text { No. of respondents } \\
\mathbf{n = 9 6}\end{array}$ & $\begin{array}{c}\text { Percentage respondents } \\
\text { \% }\end{array}$ \\
\hline Less than one year & 30 & 31.25 \\
\hline $1-5$ years & 50 & 52.8 \\
\hline 5 -10 years & 25 & 26.04 \\
\hline More than 10 yrs. & 14 & 14.58 \\
\hline
\end{tabular}

Source: Field data (2018)

The study found that $21 \%$ of the respondents had operated for $5-10$ years, $12 \%$ of the respondents had operated for more than 10 years, $42 \%$ of the respondents had operated for $1-5$ years and $25 \%$ of the respondents had operated for less than one year years. The composition of respondents in terms of their duration of operation confirms that these were respondents with the correct information on the activities in the Cargo clearance business.

\section{Descriptive statistics analysis results}

7.1 Ship Manifest Procedures

The survey therefore sought to determine if Ship manifest procedures affect cargo clearance efficiency at the port of Mombasa.

The combined stakeholders are shown on table below;

Table 4 - Ship Manifest Procedures rating

\begin{tabular}{|c|c|c|c|c|}
\hline \multicolumn{5}{|l|}{ Descriptive Statistics } \\
\hline Variable Measured & Mean & $\begin{array}{l}\text { Std. } \\
\text { Deviation }\end{array}$ & \begin{tabular}{|l|l|}
$\%$ \\
Score
\end{tabular} & Interpretation \\
\hline $\begin{array}{l}\text { The time taken to lodge a ship manifest has reduced } \\
\text { significantly. }\end{array}$ & 3.71 & .893 & 52 & Agree \\
\hline $\begin{array}{l}\text { The process of submitting of shipping documents e.g. Impeding } \\
\text { Arrival Reports IARs has improved }\end{array}$ & 3.89 & .916 & 59 & Agree \\
\hline $\begin{array}{l}\text { The time taken to lodge a Consolidation } \& \text { process manifest has } \\
\text { improved significantly }\end{array}$ & 3.50 & .649 & 57 & Agree \\
\hline $\begin{array}{l}\text { The time taken to process a ship manifest } \& \text { amendments has } \\
\text { reduced significantly }\end{array}$ & 3.43 & .778 & 57 & Agree \\
\hline Overall index score & 3.61 & 0.809 & 56.25 & Agree \\
\hline
\end{tabular}

Source: Field data (2018)

Table 4 above provides the analysis of the efficiency of Ship Manifest procedures in relation to implementation of Single Window System in Kenya. The analysis was done considering all the 7 categories of stakeholders together. Most respondents agreed that the time taken to lodge a ship manifest has improved significantly $(\mathrm{M}=$ 3.71), the process of submitting of shipping documents e.g. Impeding Arrival Reports IARs has improved $(\mathrm{M}=$ 3.89), The time taken to lodge a Consolidation \& process manifest has improved significantly (3.50) and The time taken to process a ship manifest \& amendments has reduced significantly (3.43). 
On overall the average mean response was 3.61 meaning that that the majority of the respondents agreed to the statements in the questionnaire. The standard deviation was 0.809 meaning the responses were clustered around the mean responses. The results of the study were in line with study conducted by UNCTAD (2003) that with implementation of the Single Window system, there is faster processing of ship documents which has in-turn reduced the clearance time. This was achieved through elimination of submission of hard copies to Customs and also the port authority. UN/CEFACT (2004) also observed that the countries have successfully implemented the system, their shipping procedures has greatly improved. Mikuriya (2001) also noted that with the implementation of the system in Japan, time taken to file shipping documents has reduced significantly leading reduced clearance time. The study also revealed what Muyenjwa D.D. (2004) observed in his study that the use of technology gives the customs better targets and productivity. Accordingly, express carriers electronically transmit details of manifest to the New Zealand customs which saves time and paperwork by replacing the old manual manifest system.

\subsection{Pre-clearance Permits Procedures}

The stakeholders are known to be satisfied with Cargo clearance efficiency when the Pre-clearance Permits Procedures are efficient. The survey therefore sought to find their views about performance of the procedure with the implementation Single Window system in Kenya.

The combined stakeholders are shown on table below;

Table 5- Pre-clearance Permits Procedures

\begin{tabular}{|l|c|c|c|c|}
\hline \multicolumn{1}{|c|}{ Variable Measured } & Mean & $\begin{array}{c}\text { Std. } \\
\text { Deviation }\end{array}$ & $\begin{array}{c}\text { \% } \\
\text { Score }\end{array}$ & Interpretation \\
\hline $\begin{array}{l}\text { Payment of permits by Exporters \& Importers has been made } \\
\text { easier and faster. }\end{array}$ & 3.79 & .541 & 73 & Agree \\
\hline $\begin{array}{l}\text { Generation of performance reports is faster and efficient } \\
\text { Time taken to lodge permits has reduced significantly }\end{array}$ & 4.25 & .598 & 67 & Agree \\
\hline Time taken to process permits has reduced significantly & 4.46 & .49559 & 78 & Agree \\
\hline \multicolumn{1}{|c|}{ Overall index score } & $\mathbf{4 . 1 4 5}$ & $\mathbf{0 . 6 1 9}$ & $\mathbf{7 0 . 7 5}$ & Agree \\
\hline
\end{tabular}

Source: Field data (2018)

Table 5 above provides the analysis of the efficiency Pre-clearance permits procedures in relation to implementation of Single Window System in Kenya. The analysis was done considering all the 7 categories of stakeholders together. Most respondents agreed that Payment of permits by Exporters \& Importers has been made easier and faster. ( $M=3.79)$, Generation of performance reports is faster and efficient $(M=4.25)$, the Time taken to lodge permits has reduced significantly (4.0833 and Time taken to process permits has reduced significantly (4.46).

On overall the average mean response was 4.145 meaning that that the majority of the respondents agreed to the statements in the questionnaire. The standard deviation was 0.619 meaning the responses were clustered around the mean responses. The results of the study were in line with study conducted by UN/CEFACT (2004), which found that, the system implementers stand to gain benefits ranging from improved revenue yields, Improved trader compliance, enable the use of sophisticated "risk management" techniques for control and enforcement purposes. Mwajita (2016) observes that The SWS provides a single point of interaction between Government Agencies, Traders, Clearing Agents and Financial Institutions. This greatly reduced processing time of documentation of consignments that are being imported, exported or transited through Kenya.

Kostovski (2011), also noted that there is increase compliance with regulatory requirements by merchants involved in cross border trader due to exchange of trade information to various agencies using the system. This is through facilitating trade by speeding up the process of obtaining licenses, providing savings in terms of time, human resources and costs, and generally, in facilitating the activities of economic operators.

\subsection{Customs Goods Declaration Procedures}

The stakeholders are known to be satisfied with Cargo clearance efficiency when the Customs Goods Declaration Procedures are efficient. The survey therefore sought to find their views about performance of the procedure with the implementation Single Window system in Kenya.

The combined stakeholders are shown on table below; 
Table 6 - Customs Goods Declaration Procedures

\begin{tabular}{|c|c|c|c|c|}
\hline \multicolumn{5}{|c|}{ Descriptive Statistics } \\
\hline Variable Measured & Mean & $\begin{array}{c}\text { Std. } \\
\text { Deviation }\end{array}$ & $\begin{array}{c}\% \\
\text { Score }\end{array}$ & Interpretation \\
\hline $\begin{array}{l}\text { Lodgment and processing of Imports declaration form } \\
\text { has improved significantly. }\end{array}$ & 3.33 & .879 & 52 & Agree \\
\hline $\begin{array}{l}\text { Lodging and processing of Customs declaration has } \\
\text { been made easier and transparent. }\end{array}$ & 3.72 & .736 & 63 & Agree \\
\hline $\begin{array}{l}\text { Compliance with Customs procedures has improved } \\
\text { significantly. }\end{array}$ & 3.59 & .734 & 56 & Agree \\
\hline $\begin{array}{l}\text { There is greater coordination of verification process } \\
\text { between Customs and PGAs. }\end{array}$ & 3.34 & .662 & 52 & Neutral \\
\hline $\begin{array}{l}\text { Time taken to declare goods to Customs has reduced } \\
\text { significantly }\end{array}$ & 2.74 & .920 & 58 & Disagree \\
\hline Overall index score & 3.344 & 0.7862 & 56.2 & Agree \\
\hline
\end{tabular}

Source: Field data (2018)

Table 6 provides the analysis of the efficiency in Customs goods declaration procedure in relation to implementation of Single Window System in Kenya. The analysis was done considering all the 7 categories of stakeholders together. Most respondents agreed lodgment and processing of Imports declaration form has improved significantly. $(\mathrm{M}=3.33)$, Lodging and processing of Customs declaration has been made easier and transparent. $(\mathrm{M}=3.72$. The respondents also agreed that compliance with Customs procedures has improved significantly. $(M=3.59)$. The respondents however were neutral that there is greater coordination of verification process between Customs and PGAs. $(\mathrm{M}=3.34)$. The respondents Time taken to declare goods to Customs has reduced significantly $(\mathrm{M}=2.74)$.

On overall the average mean response was 3.344 meaning that that the majority of the respondents agreed to the statements in the questionnaire. The standard deviation was 0.7862 meaning the responses were clustered around the mean responses.

The study concurs with a study conducted by ESCWA (2011) which observed that the Single windows implementation brings efficiency and productive use of resources; More comprehensive, streamlined and automated business compliance to Government legislative and regulatory requirements, including the terms of international trade treaties; Cost reductions through minimized clerical efforts, time taken to reduce and to eliminate delays, and more predictable, reliable and authoritative decisions; Faster goods clearance, exception handling and dispute resolution, leading to reduced inventory holding costs; Predictable and reliable consignment clearance and availability of advanced goods release information.

The study is also in-line with KRA time release study (2004) which confirms that the use of Information Communication Technology can improve the control and risk assessment of a customs administration and at the same time allow for a reduction in release time.

The study also confirms what Maniego (1999) noted earlier that, Philippine customs reduced the time for cargo release from the customs custody from 6-8 days to 4-6 hours for "green channel" shipments and 48 hours for other shipments by introducing an EDI system based on UNCTAD's ASYCUDA++ Chinese Taipei used to spend 10 to 15 hours for customs clearance of air cargo. Thanks to the use of EDI and pre-arrival screening, actual clearance after the arrival of vessels takes merely two to four hours.

\subsection{Cargo Clearance Efficiency}

The stakeholders are known to be satisfied when Cargo clearance procedures are efficient. The survey therefore sought to find their views about performance of the procedures at the port of Mombasa with the implementation Single Window system in Kenya.

The combined stakeholders are shown on table below; 
Table 7 - Cargo Clearance Efficiency

\begin{tabular}{|c|c|c|c|c|}
\hline \multicolumn{5}{|c|}{ Descriptive Statistics } \\
\hline \begin{tabular}{|l|} 
Variable Measured \\
\end{tabular} & Mean & $\begin{array}{c}\text { Std. } \\
\text { Deviation }\end{array}$ & $\begin{array}{c}\% \\
\text { Score }\end{array}$ & Interpretation \\
\hline $\begin{array}{l}\text { The cargo dwell time at the port of Mombasa has reduced } \\
\text { significantly }\end{array}$ & 3.10 & .946 & 50 & Agree \\
\hline $\begin{array}{l}\text { Cargo clearance time at the port of Mombasa has improved } \\
\text { significantly }\end{array}$ & 3.09 & .697 & 57 & Neutral \\
\hline $\begin{array}{l}\text { Compliance with regulatory requirements has improved } \\
\text { significantly }\end{array}$ & 3.43 & .791 & 60 & Agree \\
\hline $\begin{array}{l}\text { There is increase revenue collection by regulatory agencies at } \\
\text { the port of Mombasa }\end{array}$ & 3.36 & .896 & 53 & Agree \\
\hline $\begin{array}{l}\text { There is faster lodgment \& processing of regulatory documents } \\
\text { by Traders }\end{array}$ & 3.33 & .867 & 51 & Agree \\
\hline Overall index score & 3.262 & 0.8394 & 54.2 & Agree \\
\hline
\end{tabular}

Source: Field data (2018)

Table 7 provides the analysis of the efficiency in Cargo Clearance Efficiency in relation to implementation of Single Window System in Kenya. The analysis was done considering all the 7 categories of stakeholders together. The respondents agreed that cargo dwell time at the port Mombasa has reduced significantly $(\mathrm{M}=3.10)$. The respondent were neutral that Cargo clearance time at the port of Mombasa has improved significantly $(\mathrm{M}=3.09)$. However the respondents agreed that, Compliance with regulatory requirements has improved significantly (3.43) and also there is increase revenue collection by regulatory agencies at the port of Mombasa $(\mathrm{M}=3.33)$. There is faster lodgment \& processing of regulatory documents by Traders $(\mathrm{M}=3.53)$.

On overall the average mean response was 3.262 meaning that that majority of the respondents agreed to the statements in the questionnaire. The standard deviation was 0.8394 meaning the responses were clustered around the mean responses.

The study inferred that there is improvement in cargo clearance efficiency with the implementation of Single Window system at the port of Mombasa. This is in tandem with study finding, Tosevska and Trpcevska (2011), which established that after implementation of Single Window system in Macedonia, stakeholders both from government and private sector were able to reap benefits from efficiency brought by the system, these include; time, cost and human resource savings, improved communication and resolution of problems. The study also confirms what Maniego (1999) noted earlier that, Philippine customs reduced the time for cargo release from the customs custody from 6-8 days to 4-6 hours for "green channel" shipments and 48 hours for other shipments by introducing an EDI system based on UNCTAD's ASYCUDA++ Chinese Taipei used to spend 10 to 15 hours for customs clearance of air cargo. Thanks to the use of EDI and pre-arrival screening, actual clearance after the arrival of vessels takes merely two to four hours.

\section{Inferential statistics analysis results}

8.1 Correlation

The study used Pearson correlation to measure the degree of association between the variables under consideration. The Pearson correlation coefficient range from -1 (negative correlation) to 1 (positive correlation). Pearson coefficient of $<0.3$ indicate a weak correlation, $>0.3<0.5$ indicate a moderate correlation and $>0.5$ indicate strong correlation. 
Table 8 - Pearson Correlations summary

\begin{tabular}{|c|c|c|c|c|c|}
\hline & & $\begin{array}{l}\text { MEAN for } \\
\text { Ship Manifest } \\
\text { Procedures }\end{array}$ & $\begin{array}{l}\text { MEAN for } \\
\text { Pre-clearance } \\
\text { Permits } \\
\text { Procedures }\end{array}$ & $\begin{array}{l}\text { MEAN for } \\
\text { Customs } \\
\text { Goods } \\
\text { Declaration } \\
\text { Procedures }\end{array}$ & $\begin{array}{l}\text { MEAN for } \\
\text { Cargo } \\
\text { Clearance } \\
\text { Efficiency }\end{array}$ \\
\hline \multirow{3}{*}{$\begin{array}{l}\text { MEAN for Ship } \\
\text { Manifest Procedures }\end{array}$} & \begin{tabular}{|l|} 
Pearson Correlation \\
\end{tabular} & 1 & $.914^{* *}$ & $.941^{* *}$ & $.952^{* *}$ \\
\hline & Sig. (1-tailed) & & .000 & .000 & .000 \\
\hline & $\mathrm{N}$ & 96 & 96 & 96 & 96 \\
\hline \multirow{3}{*}{$\begin{array}{l}\text { MEAN for Pre-clearance } \\
\text { Permits Procedures }\end{array}$} & Pearson Correlation & $.914^{* *}$ & 1 & $.890^{* *}$ & $.861^{* *}$ \\
\hline & Sig. (1-tailed) & .000 & & .000 & .000 \\
\hline & $\mathrm{N}$ & 96 & 96 & 96 & 96 \\
\hline \multirow{3}{*}{$\begin{array}{l}\text { MEAN for Customs } \\
\text { Goods Declaration } \\
\text { Procedures }\end{array}$} & \begin{tabular}{|l|} 
Pearson Correlation \\
\end{tabular} & $.941^{* *}$ & $.890^{* *}$ & 1 & $.950^{* *}$ \\
\hline & Sig. (1-tailed) & .000 & .000 & & .000 \\
\hline & $\mathrm{N}$ & 96 & 96 & 96 & 96 \\
\hline \multirow{3}{*}{$\begin{array}{l}\text { MEAN for Cargo } \\
\text { Clearance Efficiency }\end{array}$} & Pearson Correlation & $.952^{* *}$ & $.861^{* *}$ & $.950^{* *}$ & 1 \\
\hline & Sig. (1-tailed) & .000 & .000 & .000 & \\
\hline & $\mathrm{N}$ & 96 & 96 & 96 & 96 \\
\hline
\end{tabular}

Source: Field data (2018)

The analysis above show that Ship manifest procedures has the strongest (Pearson correlation coefficient $=.952$; $\mathrm{P}$ values 0.000) influence on Cargo clearance efficiency. In addition, Pre-clearance permit procedures and Customs goods declaration procedures are positively correlated to Cargo clearance efficiency (Pearson correlation coefficient $=.861 \& .950$ ). The correlation implies that the independent variables have an effect of Cargo clearance efficiency as shown by their strong and positive relationship with the independent variable.

\subsection{Regression analysis}

Table 9 - Model summary

\begin{tabular}{|l|c|c|c|c|}
\hline \multicolumn{7}{|c|}{ Model Summary } \\
\hline Model & R & R Square & Adjusted R Square & Std. Error of the Estimate \\
\hline 1 & $.967^{\mathrm{a}}$ & .935 & .932 & .205 \\
\hline
\end{tabular}

a. Predictors: (Constant), MEAN for Customs Goods Declaration Procedures, MEAN for Pre-clearance Permits Procedures, MEAN for Ship Manifest Procedures

\section{Source: Field data (2018)}

The 3 independent variables that were studied and explained $93.5 \%$ of the Cargo clearance efficiency as represented by the $\mathrm{R}^{2}$. This means that others factors not under this study contribute to $6.5 \%$ of cargo clearance efficiency at the port of Mombasa and need to be considered an effort to improve cargo clearance efficiency. The Multiple Correlation Coefficient, $\mathrm{R}=0.967$ indicates a good level of prediction.

\subsection{Analysis of Variance ANOVA}

The table below shows the output of the ANOVA analysis. It shows whether there is a statistically significant difference between our group means. The results of the analysis on table 4.9 showed that, significance value is 0.00 (i.e., $p=.000$ ), which is below 0.05 . And, therefore, there is a statistically significant difference in between the groups in each category. This also indicates that the predictor variables, (Customs Goods Declaration Procedures, Pre-clearance Permits Procedures, and Ship Manifest Procedures) explain the variation of the dependent variable which is Cargo clearance efficiency.

Table 10 - Analysis of Variance

\begin{tabular}{|c|c|c|c|c|c|c|}
\hline \multicolumn{7}{|c|}{ ANOVA $^{a}$} \\
\hline & & Sum of Squares & $\mathrm{df}$ & Mean Square & $\mathrm{F}$ & Sig. \\
\hline \multirow{3}{*}{1} & Regression & 55.239 & 3 & 18.413 & 438.442 & $.000^{\mathrm{b}}$ \\
\hline & Residual & 3.864 & 93 & .042 & & \\
\hline & Total & 59.102 & 96 & & & \\
\hline \multicolumn{7}{|c|}{ a. Dependent Variable: MEAN for Cargo Clearance Efficiency } \\
\hline \multicolumn{7}{|c|}{$\begin{array}{l}\text { b. Predictors: (Constant), MEAN for Customs Goods Declaration Procedures, MEAN for Pre-clearance Permits } \\
\text { Procedures, MEAN for Ship Manifest Procedures }\end{array}$} \\
\hline
\end{tabular}

Source: Field data (2018) 


\subsection{Multiple regression model}

The Regression model is used here to show how the mean of dependent variable changes with the changing conditions. Regression analysis was carried out focusing means for Ship manifest procedures, Pre-clearance permit procedures, Customs goods declaration procedures and Cargo clearance efficiency. To test the relationship the independent variables have on Cargo clearance efficiency, the study used the following multiple regression analysis.

Table 11 - Multiple Regression Model Results

\begin{tabular}{|c|c|c|c|c|c|c|}
\hline \multirow{2}{*}{\multicolumn{2}{|c|}{ Model }} & \multicolumn{2}{|c|}{$\begin{array}{l}\text { Unstandardized } \\
\text { Coefficients }\end{array}$} & \multirow{2}{*}{$\begin{array}{c}\text { Standardized } \\
\text { Coefficients } \\
\text { Beta }\end{array}$} & \multirow[t]{2}{*}{$\mathrm{t}$} & \multirow[t]{2}{*}{ Sig. } \\
\hline & & $\mathrm{B}$ & Std. Error & & & \\
\hline & (Constant) & .028 & .227 & & .124 & .901 \\
\hline & MEAN for Ship Manifest Procedures & .626 & .094 & .606 & 6.673 & .000 \\
\hline 1 & $\begin{array}{l}\text { MEAN for Pre-clearance Permits } \\
\text { Procedures }\end{array}$ & -.228 & .105 & -.146 & $\begin{array}{r}- \\
2.169\end{array}$ & .033 \\
\hline & $\begin{array}{l}\text { MEAN for Customs Goods Declaration } \\
\text { Procedures }\end{array}$ & .571 & .091 & .509 & 6.283 & .000 \\
\hline
\end{tabular}

Source: Field data (2018)

The regression model that was used to predict Cargo clearance efficiency from Ship manifest procedures, Preclearance permit procedures and Customs good declaration procedures is $\left(Y=\beta_{0}+\beta_{1} X_{1}+\beta_{2} X_{2}+\beta_{3} X_{3}+e\right.$ ) Where, $Y=$ Cargo clearance efficiency, $\beta_{0}=$ Constant Term, $\beta_{1}=$ Beta coefficients, $X_{1}=$ Ship manifest procedures, $\mathrm{X}_{2}=$ Pre-clearance permit procedures and $\mathrm{X}_{3}=$ Customs good declaration procedures. This is summarized as follows: $\mathrm{y}=0.28+\left(0.626 * \mathrm{X}_{1}\right)-\left(0.228 * \mathrm{X}_{2}\right)+\left(0.571 * \mathrm{X}_{3}\right)+0.227$. This means that when all factors are held constant Cargo clearance efficiency at the port of Mombasa was 0.028. This indicates that an improvement in Ship manifest procedures leads to 0.626 efficiency in in cargo clearance at the port of Mombasa, an improvement of Pre-clearance Permits Procedures leads to -0.228 and improvement of Customs Goods Declaration Procedures leads to 0.571 improvement in cargo clearance efficiency at the port of Mombasa. The results are in-line with study by Tosevska and Trpcevska (2011), which established that after implementation of Single Window system in Macedonia, stakeholders both from government and private sector were able to reap benefits from efficiency brought by the system, these include; time, cost and human resource savings, improved communication and resolution of problems. The findings also agree UNCTAD (2003) observed that with the implementation of the system brings faster processing of ship documents which has in-turn reduced the clearance time. The study concurs with a study conducted by ESCWA (2011) which observed that the Single windows implementation brings efficiency and productive use of resources; More comprehensive, streamlined and automated business compliance to Government legislative and regulatory requirements, including the terms of international trade treaties; Cost reductions through minimized clerical efforts, time taken to reduce and to eliminate delays, and more predictable, reliable and authoritative decisions; Faster goods clearance, exception handling and dispute resolution, leading to reduced inventory holding costs; Predictable and reliable consignment clearance and availability of advanced goods release information.

\section{Discussion}

The study sought to analyze the effect of Single Window System procedures on cargo clearance efficiency at the port of Mombasa. The research study revealed that the launch and implementation of Single window System operations led to an affirmative increase in efficiency in cargo clearance at the port of Mombasa. The test statistics conducted denoted a statistically significant deviation between the means of Single Window procedures.

\subsection{Ship manifest procedures}

The research study determined that Ship Manifest Procedures affected cargo clearance efficiency at the port of Mombasa. This was evident with most respondents agreeing that the procedures have improved with the implementation of Single Window system in Kenya having an overall index of $56.25 \%$, Mean=3.68 and Standard deviation of 0.809 less than $(\mathrm{SD} \leq 1)$. On measure of correlation, Ship manifest procedures had the strongest (Pearson correlation coefficient $=.952$; P values 0.000 ) influence on Cargo clearance efficiency. The results agree with a study by UNCTAD (2003) observed that with the implementation of the system, there is faster processing of ship documents which has in-turn reduced the clearance time. This has been achieved through elimination of submission of hard copies to Customs and also the port authority. UN/CEFACT (2004) also observed that the countries have successfully implemented the system, their shipping procedures has greatly improved. Mikuriya (2001) also noted that with the implementation of the system in Japan, time taken to file 
shipping documents has reduced significantly leading reduced clearance time.

9.2 Pre-clearance permit procedures

More specifically the study established that Pre-clearance permit procedures affect cargo clearance efficiency at Mombasa port. The respondents agreed that Pre-clearance permit procedures have improved with the implementation of Single Window system in Kenya having an overall index score of $70.75 \%$, Mean $=4.145$ and Standard deviation of 0.619 less than $(\mathrm{SD} \leq 1)$.

In addition, Pre-clearance permit procedures (Pearson correlation coefficient $=.861 ; \mathrm{P}$ values 0.000 ) influence on cargo clearance efficiency. This is in line with study conducted by UN/CEFACT (2004), which found that, the system implementers stand to gain benefits ranging from improved revenue yields, Improved trader compliance, enable the use of sophisticated "risk management" techniques for control and enforcement purposes. Mwajita (2016) observes that The SWS provides a single point of interaction between Government Agencies, Traders, Clearing Agents and Financial Institutions. This has greatly reduced processing time of documentation of consignments that are being imported, exported or transited through Kenya.

Kostovski (2011), also noted that there is increase compliance with regulatory requirements by merchants involved in cross border trader due to exchange of trade information to various agencies using the system. This is through facilitating trade by speeding up the process of obtaining licenses, providing savings in terms of time, human resources and costs, and generally, in facilitating the activities of economic operators.

\subsection{Customs goods Declaration procedures}

The study also found that that Customs goods declaration procedures affect cargo clearance efficiency at the port of Mombasa. The respondents agreed that Customs goods declaration procedures have improved with the implementation of Single Window system in Kenya having an overall index score of $56.2 \%$, Mean $=3.311$ and Standard deviation of 0.7862 less than (SD $\leq 1$ ). Customs goods declaration procedures were positively correlated to Cargo clearance efficiency (Pearson correlation coefficient $=.950 ; \mathrm{P}$ value 0.000 ) influence on cargo clearance efficiency.

The respondents agreed that Customs goods declaration procedures have improved with implementation of Single Window system at the port of Mombasa. The study concurs with a study conducted by ESCWA (2011) which observed that the Single windows implementation brings efficiency and productive use of resources; More comprehensive, streamlined and automated business compliance to Government legislative and regulatory requirements, including the terms of international trade treaties; Cost reductions through minimized clerical efforts, time taken to reduce and to eliminate delays, and more predictable, reliable and authoritative decisions; Faster goods clearance, exception handling and dispute resolution, leading to reduced inventory holding costs; Predictable and reliable consignment clearance and availability of advanced goods release information.

The study also confirms what Maniego (1999) noted earlier that, Philippine customs reduced the time for cargo release from the customs custody from 6-8 days to 4-6 hours for "green channel" shipments and 48 hours for other shipments by introducing an EDI system based on UNCTAD's ASYCUDA++ Chinese Taipei used to spend 10 to 15 hours for customs clearance of air cargo. Thanks to the use of EDI and pre-arrival screening, actual clearance after the arrival of vessels takes merely two to four hours

\subsection{Cargo clearance efficiency}

The study revealed that Single Windows system procedures have an effect on cargo clearance efficiency. The respondents agreed that there is greater efficiency in Cargo clearance with the implementation of Single Window system at the having overall index score of $54.2 \%$, Mean=3.262 and a standard deviation of 0.8394 less than (SD $\leq 1)$.

\section{Conclusions of the Study}

It is evident from the study that the implementation of Single Window system has Leading to increased efficiency at the port Mombasa. This is evident that on Ship Manifest procedures, there is faster lodgment and processing of manifest, improved process of submitting IARs, improved turn around for ships and reduced cargo dwell time.

On Pre-Clearance permit procedures efficiency is also noted in cost savings achieved by traders, less time taken to lodge \& process permits, increased compliance and revenue collection by regulatory agencies.

On Customs good declaration procedures, the implementation of the system has also resulted in increase in revenue collection, less time taken to lodge \& process Customs clearance documents, increased transparency \& accountability.

\section{Recommendations}

Overall there is need for the government to streamline the cargo clearance at the Port of Mombasa by reengineering of clearance some process. One of the recommendation is to allow advance lodgments of manifest 
when vessels leave other ports to Kenya. There is also need for the port operator and Customs to automate some of the manual procedures such a CFS nominations to enable faster clearance of goods at the port and employ more staff to address gaps leading to lengthy clearance process.

The government also needs to look at conflicting/ duplication roles of some regulatory agencies managing the Pre-clearance procedures. The government may also need change some laws which requires input of manual operation such stamping of clearance documents. The government needs also to improve port infrastructure such internet, road way which will improve flow of trucks and also faster processing of documents. There is also need to train of the various agencies staff at the port on the dynamics of business or emerging trends to enable them change with time.

\section{References}

Abeywickrama, M. and Wickramarachchi A. (2015). Study on the Challenges of Implementing Single Window Concept to Facilitate Trade in Sri Lanka: A Freight Forwarder Perspective.

African Alliance for e-Commerce Task Force April (2013), Guidelines for Single Widow Implementation in Africa.

African Union (2015), African Union Expert Group Workshop on Implementation of Single Window System.

Alex. K (2014), Case of the Kenya National Electronic Single Window System (Kenya TradeNet system)

Al-Khaffaf, M. (2012). Applying Change Management Critical Success Factors in Bank of Jordan and Capital Bank. American Academic and Scholarly Research Journal, Vol. 14.

Allan. O (2013), "EAC passes law on One Stop Border Posts, Business Daily.

Alexander S, (2002) "Non-linear change in organizations: organization change management informed by complexity theory", Leadership \& Organization Development Journal

ASEAN Secretariat (2013), Factsheet: ASEAN Economic Community (ASC).

Baker and Nelson, (2005). Creating Something from Nothing: Resource Construction through Entrepreneurial Bricolage

Bausch, K. C. 2002. Roots and branches: a brief, picaresque, personal history of systems theory. Systems Research and Behavioral Science

Beri, G. C. (2007). Marketing research. Tata McGraw-Hill Education.

Byeon, J. H. (2005), A systems approach to entropy change in political systems. Syst. Res.

Bukuku, E. (Deputy Secretary General of Planning and Infrastructure in the EAC) (2012), Progress on the EAC Monetary Union. (Unpublished document).

CAO G, (2005). A Systemic View of Change Management and Its Conceptual Underpinnings. Systemic Practice and Action Research. 18. 475-490. 10.1007/s11213-005-8484-4.

Capps, C. and Hazen, S.E. 2002. Applying general systems theory to the strategic scanning of the environment from 2015 to 2050. International Journal of management

Charles A. (2007). What Business Reengineering Means. Retrieved September 112017 from http://allafrica.com/stories/200712240283.html

Choi, J Y. "A survey of single window implementation." WCO Research Paper 17 (2011): 11-20.

Crispino, L. (2008). Institutional and Organizational Analysis for Pro-poor Change: Meeting IFAD's Millennium Challenge. Rome, Italy: International Fund for Agricultural Development.

Christopher M, (2008) Change Management Best Practices Guide Five (5) key factors common to success in managing organizational change.

Cooper, D.R \& Schindler, P.S (2000). Business Research Methods. New York: McGraw Hill Company.

CSC Index, Inc., (1994), CSC index state of reengineering report: North America and Europe

CIU. (2012). Guide to Implementation Planning. Australia: Cabinet Implementation Unit.

Das, R. U., Edirisuriya, P., \& Swarup, A. (2012). Regional trade and economic integration: analytical insights and policy options. World Scientific.

Dahl, D. W., \& Moreau, C. P. (2007). Thinking inside the box: Why consumers enjoy constrained creative experiences. Journal of Marketing Research

Thomas D (1990), Classical reengineering

Dastur, A. (2010). The Art of Change Management: Implementing Change from the Top. Embassy Books.

David, A. (1998), The Processes of Organization and Management, Copyright (C) Massachusetts Institute of Technology, 1977-2018.

Philips, C (1969), Systems Theory - A Discredited Philosophy

Diagne, I. N. E. (2013), Single Window \&Regional Trade Integration: The Challenges, available on www.unece.org/fileadmin/DAM/Cefact/Cf_forums/Geneva_2013/PPTs/08_SingleWindowandRegionalTrad elntegration.pdf.

Director General of Customs, ASEAN Single Window (2014): The ASEAN Connectivity towards ASEAN Doing Business, 
Doing Business 2015: Going Beyond Efficiency, World Bank.

Doha ministerial conference

https://www.wto.org/english/thewto_e/minist_e/min01_e/min01_e.htm

(November

2001),

Draft, E. (1999). Project Financial Management Manual. Loan Department World Bank, February.

Mugendi E.(2016), Kenya's Ecitizen Portal is Saving the Government a Ton of Money From http:/techcabal.com/2016/08/05/kenyas-ecitizen-portal-is-saving-the-government-a-ton-of-money/

Hoegl, M., Gibbert, M., \& Mazursky, D. (2008). Financial constraints in innovation projects: When is less more? Research Policy.

Garud, R., \& Karnoe, P. (2003). Bricolage versus breakthrough: distributed and embedded agency in technology entrepreneurship. Research policy.

Gichoya, D. (2005). Factors affecting the successful implementation of ICT projects in government. The Electronic Journal of e-government.

Goldenberg, J., Lehmann, D. R., \& Mazursky, D. (2001). The idea itself and the circumstances of its emergence as predictors of new product success. Management science.

Guy, G., \& and Beaman, V. (2005). Effecting Change in Business Enterprises: In Current Trends in Change Management. The Conference Board.

Hammer \& Champy (1993), Reengineering the Corporation: A Manifesto for Business Revolution

Hermann, S. (2011). Stakeholder Management: Long term Business Success through strong Stakeholder Relationships. Germany: TNS Intratest.

Higgins, J., \& McAllaster, C. (2004). If you want Strategic Change, do not forget to change Strategic Artifacts. Journal of Change Management.

Hui-Liang T (2003). Information Technology and Business Process Reengineering. Retrieved September 12 2017 from http://www.greenwood.com/catalog/Q632.aspx.

Hultman, K. (1995). Scaling the Wall of Resistance.

ICT Authority (2016), http://www.ict.go.ke/wp-content/uploads/2016/04/MinistryStrategic.pdf

John K. (2002) The Heart of Change: Real-Life Stories of How People Change Their Organizations. Harvard Business School Press edition, ISBN 1578512549

Jim M and Jan N (2007), the Evolution of Electronic Trade Facilitation: Towards a Global Single Window Trade Portal (2007). https//www.researchgate.net/publications/228581401.

Kamau, P. (2014). Managing organizational change effectively: A case study of Kenya revenue authority (Doctoral dissertation, United States International University-Africa).

Keretho, S. (2013). Evolving National Single Windows for Supply Chain Connectivity. In Asia Pacific Trade Facilitation Forum (Vol. 4, pp. 1-27).

KenTex Cargo (2014). How to clear at the Port of Mombasa: https://kentexcargo.com/blog/how- to-clear-acontainer-at-kra-port-in-mombasa-cost-procedure-explained/

Kubai, J. M. (2015). Regional trade and the single window system: A case of the EAC (Doctoral dissertation, University of Nairobi).

Kirkpatrick, D. (2001). Scaling the Wall of Resistance. Boston: Butterworth-Heinemann.

KRA (2004), Time Release Study Report Kenya, Nairobi: KRA

Montuori, L. (2000) "Organizational longevity - Integrating systems thinking, learning and conceptual complexity", Journal of Organizational Change Management.

Leamer, E. E. (1995). The Heckscher-Ohlin model in theory and practice.

Leroy W, (2000) "Changing the "whole system" in the public sector", Journal of Organizational Change Management

Marta F. Olalls (1999) Information Technology in Business Process Reengineering. World Bank group (2012).

Martyn S (2009). Instrument Reliability. Retrieved Sep 25, 2017 from Explorable.com: https://explorable.com/instrument-reliability

McCarthy, C., \& David, E. (2010). Change Management Strategies for an Effective EMR Implementation. Chicago, USA: Himms.

Meier, J \& Conkling, T. (2008). Google Scholar's Coverage of the Engineering Literature: An Empirical Study. The Journal of Academic Librarianship. 34. 196-201. 10.1016/j.acalib.2008.03.002.

Danet, M (2007), Security concerns drive a whole new World Trade Agenda - report on the WCO Forum, December 2007

Mikuriya, K (2001)“Overview of Technical Assistance Activities by Japan custom, presentation note for the WTO workshop on Technical Assistance and Capacity Building in Trade Facilitation" (Geneva, 10-11 May 2001)

Mombasa port community (2014). Advancing Trade through the Northern Corridor. http://www.ttcanc.org/documents/Port_Comm_Charter_Final.pdf

Muyenjwa (2004); "Analysis of factors affecting freight forwarders operation in Tanzania", 
Mwajita, M. I. (2016). "The Effects of the Implementation of the Kenya National Electronic Single Window System on trade facilitation"

Wheatley M (1996), http://www.margaretwheatley.com/articles/irresistiblefuture.html

Nelson, K., \& Horne, B. (2003). In their Own Words: CIO Vision about the Future of the IT Organizations. The Database for Advance in Information Systems.

Nickols, F. (2002). Change Management.

OECD (2005), "The Role of Automation in Trade Facilitation", OECD Trade Policy Papers, No. 22, OECD Publishing, Paris. DOI: http://dx.doi.org/10.1796/841420380004.

Piderit, S. (2000). Rethinking Resistance Ambivalence: A Multidimensional view of Attitudes towards an Organizational Change. Academy of Management Review.

Prosci, B. (2009). Best Practices in Change Management.

Raymond L \& Mark M (2001). The Reengineering Handbook: A Step-By-Step Guide to Business $\begin{array}{llllll}\text { Transformation. } & \text { Retrieved } & \text { August } & 11 & 2017 & \text { from }\end{array}$ http://www.themanager.org/Knowledgebase/Management/BPR.htm\#Literature

Cyert, R \& March J (1963). A Behavioral Theory of the Firm

Roger B., (2007) "The external environment's effect on management and strategy: A complexity theory approach", Management Decision

Smith, Erin and Peter Rosenblum (2011) https://resourcegovernance.org/sites/default/files/nrgi_LegalFramework.pdf

Smyth, R. (2004). Exploring the usefulness of a conceptual framework as a research tool: $A$ researcher's reflections. Issues in educational research, 14(2), 167.

SCEA (2015), http://www.shipperscouncilea.org/

Shafritz, J. M. and Russell, E. W. 2005. Introducing public administration. (4th Ed.). New York: Pearson Education.

Tallman, D. (1992). Adult Education Perspectives for Judicial Education. Georgia: Centre for Continuing Education.

The Investment Climate Facility for Africa (2014). Businesses in Kenya benefit from improved Trade facilitation from http://www.icfafrica.org/news/businesses-in-kenya-benefit-from-improved-trade-facilitation.

Trulsson, P. (2002). Constraints of growth-oriented enterprises in the southern and eastern African region. Journal of Developmental Entrepreneurship.

Tsen, J. (2011, December). Ten years of Single Window Implementation: Lessons learned for the future. In Global Trade Facilitation Conference.

UIA (2000) The Encyclopedia of World Problems\& Human Potential http://encyclopedia.uia.org/en/problem/144411

UN/CEFACT. (2003). The Single Window Concept. Available from http://www.unece.org/cefact.html.

UNCTAD (2002) "Technical Feasibility Study - Implementation of System from version 2.7 to ASYCUDA++ in Tanzania, Washington DC

United Nation (2011), Key factors in establishing single windows for handling import/export Procedures and formalities: trade facilitation and the single window

Wang, T. (2004). From general system theory to total quality management. Journal of American Academy of Business

Weicher, M., Chu, W. Lin, W\& Yu, D. (1995). Business Process Reengineering Analysis and Recommendations. MBA and MS paper, Baruch College, City University of New York.

World Customs Organization (2011), How to build a Single Window environment; Key Factor in Establishing Single Windows for Handling Import/Export Procedures and Formalities. United Nations Publication E//ESCWA/EDGD/2011/5, 11-0286-December 2011-472.

WTO TFA, (2014).https://www.wto.org/english/tratop_eltradfa_eltradfa_e.htm

Yoon, S. \& Kuchinke, K. (2005). Systems theory and technology: Lenses to analyze an organization. Performance Improvement 